\title{
ANALYSIS OF THE CURRENT STATUS OF AVIFAUNA IN KOSTOMUKSHA STATE NATURE RESERVE AND KALEVALA NATIONAL PARK (NORTH-WEST RUSSIA), TAKING INTO ACCOUNT INFLUENCE FROM ADJACENT AREAS
}

\author{
Sergey A. Simonov", Maria V. Matantseva \\ Institute of Biology of Karelian Research Centre of RAS, Russia \\ *e-mail:Sergey.Simonov@bio.krc.karelia.ru
}

Received: 09.12.2019. Revised: 01.06.2020. Accepted: 06.06.2020.

\begin{abstract}
The paper offers an assessment of the current status of the avifauna in Kostomuksha State Nature Reserve (KNR) and Kalevala National Park (KNP). They are the two largest Protected Areas (PAs) in Russian Karelia, having a key importance for the conservation of pristine boreal ecosystems in the Green Belt of Fennoscandia. The species composition and abundance parameters of birds in these PAs are described on the basis of data from 2015-2019 and compared with data gathered in 1980-1990. We specifically address the influence of adjacent areas on the bird fauna of the PAs. First of all, it was the potential effect of recently logged areas in the vicinity of the protected territories on avifauna in their periphery. The studies were carried out as transect counts and point counts with the resultant data processing in R environment. Comparison with data obtained in 1980-1990 corroborates the hypothesis about a species turnover of boreal ecosystems in the direction of increasing the ratio of southern species. The observed species turnover in the PAs is consistent with the ideas about ongoing global species turnover due to climate change. As for the anthropogenic load on ecosystems, until now, no critical effect of logged areas adjoining KNR and KNP on the avifauna in these PAs has been detected. Presumably, the pressure on the ecosystems is alleviated by the size of the PAs and the scope of their conservation. Arguably, if the key current parameters of the PAs are maintained, in KNR and KNP, the natural bird fauna would be preserved in spite of the increased anthropogenic pressure in adjacent areas. However, it cannot be ruled out, that as the logged area around the PAs expands, and the number of species associated with open habitats increases accordingly, some of them may disperse into the transformed habitats available in the PAs. Hence, monitoring of the avifauna in these PAs should be continued, especially in their periphery, considering the tendencies for an increase in the concentration of southern bird species and widespread species near the disturbed areas. The highest threat contained in continuing logging around the PAs is a farther spread and a rise in the numbers of species not typical of boreal ecosystems. Thus, logging can contribute to the species turnover induced by climate change and exacerbate the situation. Such a shift in the ratio of northern and southern birds may, in turn, jeopardise the balance in boreal communities and thereby increase their vulnerability.
\end{abstract}

Key words: birds, climate change, edge effects, human impact, logging, Protected Area, protected species, rare species, taiga

\section{Introduction}

Significant changes in bird communities have been observed all around the world. Birds respond on climate change and land use, and both these factors can be highly important (Segan et al., 2016; Bowler et al., 2018; Yalcin \& Leroux, 2018; Brotons et al., 2019). Under climate change and habitat loss, global biodiversity is decreasing (Thomas et al., 2004; Pimm, 2008; Butchart et al., 2010; Hoffmann et al., 2010; Pearce-Higgins et al., 2015), and a species turnover and range shifts have been registered in many regions (Parmesan, 2006; Devictor et al., 2008, 2012; Huntley et al., 2008; Jiguet et al., 2010; Chen et al., 2011; Lindström et al., 2013; Garcia et al., 2014; Roth et al. 2014; Lehikoinen \& Virkkala, 2016; Yang et al., 2020). All these disturbing changes require immediate actions, and one of them is to preserve the native avifauna, inter alia by the arranging of Protected Areas (PAs) (Rodrigues et al., 2004;
Gaston et al., 2008; Virkkala et al., 2008; Venter et al., 2014; Watson et al., 2014; Gillespie, 2020).

Despite the mismatch between species range shifts and the stable location of PAs (Heller \& Zavaleta, 2009; Thomas \& Gillingham, 2015), they are still considered to reduce the negative effects of climate change on communities and contribute to species conservation (Thomas et al., 2012; Virkkala et al., 2014, 2018; Gillingham et al., 2015; Thomas \& Gillingham, 2015; Santangeli et al., 2017; Lehikoinen et al., 2018). Thus, in the light of climate change and other anthropogenic loads on ecosystems as well as the significant role of PAs in bird preservation, the assessment of the current state of their avifauna is becoming especially relevant.

Studies devoted to this problem are requested worldwide. In particular, such investigations have been actively conducted in Russia and adjacent areas (Koshkin, 2003; Iovchenko, 2011; Naumkin, 2011, 2013; Sokolov, 2012; Nankinov \& Nanki- 
nov, 2013; Batt, 2015; Belik, 2015; Czeszczewik et al., 2015; Gluschenko \& Korobov, 2015; Kopij, 2015; Mnatsekanov \& Tilba, 2015; Reznichenko, 2015; Volkov, 2016; Kolbin, 2017; Belik, 2018; Buzun et al., 2018; Nacharkin \& Govorova, 2018; Fetisov, 2019; Kondratyev et al., 2019; Hasanova, 2019). Concerning the region under our investigation, of particular importance are studies conducted in the countries of Northern Europe bordering Russia, such as Norway (Mjøs, 2002; Anker-Nilssen, 2006; Olsen \& Mjølsnes, 2007; Olsen et al., 2008), Finland (Santangeli et al., 2017; Fraixedas et al., 2017; Virkkala et al., 2018), and the Baltic countries (Fraixedas et al., 2017; Marja \& Nellis, 2018; Elts et al., 2019; Nellis \& Volke, 2019).

The study of northern habitats occupies an important place among such research. In the northern taiga regions, the loss of pristine habitats, especially forests, due to commercial use, is one of the main problems in relation to local fauna preservation. Besides the loss of forests itself, a shift in the ratio of mature forests and young age habitats are increasing. These problems can be the causes of changes in bird communities, and they are relevant to northern taiga regions (e.g. Fraixedas, 2017; Mäntyranta, 2019). Another type of highly threatened ecosystems there is peatland habitats (Fraixedas et al., 2017). Despite this fact, there is a deficit of research on the state of bird communities in peatlands (Fraixedas et al., 2017).

Addressing these problems, in northern regions, PAs with pristine forests and peatlands can play the main role in bird species preservation. Indeed, there is some evidence that PAs contribute to maintaining the community of northern species (e.g. Virkkala et al., 2014, 2018; Santangeli et al., 2017), and it requires investigations of the bird status in such PAs. Moreover, the Arctic Ocean is a natural barrier to species' northward range shifts (Virkkala et al., 2008), which increases the need to study bird communities and their dynamics in the northern boreal and Arctic PAs (Virkkala et al., 2018).

Kostomuksha State Nature Reserve (KNR) and Kalevala National Park (KNP) belong to the largest PAs of this type in northern Europe and can be model PAs in such research. The early history of ornithological studies in the KNR and KNP has been previously detailed (Sazonov, 1997, 2015; Zimin \& Sazonov, 1997; Simonov \& Matantseva, 2017). Here, we briefly note that avifauna research of NW Karelia began at the end of the XIX century by Finnish ornithologists. Their data were summarised and presented in Merikallio (1921). In subse- quent years, the border areas of Russian Karelia and Finland were also repeatedly surveyed (Lehtonen, 1943; Lampio, 1945; Waaramäki, 1945; Suomalainen, 1952; Merikallio, 1958). In Northwestern Karelia, directly in the area of the future KNR, specialised bird counts began in the 1970s by Zimin, Lapshin and Annenkov, the researchers belonged to the Karelian Branch of RAS, during expeditions in 1972-1975 (Danilov et al., 1977).

The largest amount of data on the species composition and abundance of birds in these areas were conducted in the late $1980 \mathrm{~s}$ - early 2000 s, i.e. about 20 years ago (Helle et al., 1983; Adrianova et al., 1990; Rajasärkkä \& Virolainen, 1990, 1995; Huttunen, 1992; Virolainen et al., 1992; Kuleshova et al., 1996; Kashevarov \& Pozdnakov, 1997; Sazonov, 1997; Zimin \& Sazonov, 1997; Zimin et al., 1998; Sazonov et al., 2002; Rajasärkkä, 2004). Later Rajasärkkä and Fayt, researchers from Finland, also conducted some bird counts in the KNP, but their data have not yet been published (Fayt, pers. comm.).

Russian ornithologists also surveyed some areas inside KNR in the spring and summer seasons in 2000 and 2009 (Sazonov, 2015). On the basis of a summary of all the collected material, conclusions were drawn about the zoogeographical status of the area, and the PA-averaged number of breeding pairs was estimated for various species. These results were successfully used for evaluating the importance of the PA for birds. But they are hardly applicable for interpreting local breeding densities, and therefore have little potential of being used for comparisons in biogeographical papers. Furthermore, these data may be no longer valid for the current situation in KNR avifauna because a majority of them was gathered over 20 years ago, and the most recent ones being 10 years old.

Also, some data from winter counts in KNR, especially on Galliformes, were published (Kashevarov, 1998; Kashevarov \& Heikkilä, 2003; Bologov \& Sikkilä, 2013; Preobrazhenskaya, 2015). These data are of high value for the analysis of the wintering avifauna in KNR but cannot be extrapolated to breeding densities in the PA.

Importantly, forests around KNR and KNP have been actively logged in the past decade (Hansen et al., 2013; Global Forest Change, 2019). Now these PAs are almost surrounded by logged areas spreading towards their borders. Thus, in a situation where we lack recent datasets on the status of avifauna in KNR and KNP, and where the fauna is influenced by the climate change, succession and impact of adjacent logged areas, there is a high de- 
mand for new ornithological surveys both in their central parts, away from the transformed habitats, and in the periphery bordering the disturbed areas. This is needed to enable the analysis of the current state of these PAs.

Our studies aimed to analyse the current status of avifauna in KNR and KNP using the material gathered in the field in 2015-2019. The first results of these studies (covering 2015-2016) have been published (Simonov \& Matantseva, 2017). Data collection in the following seasons and expansion of the area covered by surveys to include the surroundings of the PAs were designed to update the information on the species composition of birds in these PAs, their status and abundance, as well as to assess the effect of recently logged areas near the PAs on their avifauna. The working hypothesis implied a multifaceted remote detrimental effect of habitat disturbance on the abundance of birds representing the boreal avifauna, a neutral effect on the numbers of background species (see section Material and Methods), and a positive effect on the numbers of open habitat species in the territories bordering the logged areas.

\section{Material and Methods}

Kostomuksha State Nature Reserve and Kalevala National Park are among the largest PAs in the Republic of Karelia, North-West Russia. They lie in the north-west of the Republic of Karelia, near the Finnish border (Fig. 1). Their detailed physiographical descriptions can be found in Volkov et al. (1995), Lindholm et al. (1997), Gromtsev (2000, 2002, 2009), Sazonov (2015). The main characteristics of the PAs of relevance for this study are the following: (1) substantial size (KNR - ca. $500 \mathrm{~km}^{2}, \mathrm{KNP}$ - ca. $\left.750 \mathrm{~km}^{2}\right)$, (2) presence of large areas of intact pine (Pinus sylvestris L.) and spruce (Picea abies L.) forest stands older than 120 years (KNR - ca. $345 \mathrm{~km}^{2}$, $\mathrm{KNP}$ - ca. $400 \mathrm{~km}^{2}$ ), (3) large number of lake-river systems (KNR $-23.8 \%$ of the PA surface area, KNP $-12.1 \%$ ), and (4) substantial share of mires (KNR $13.3 \%$ of the PA surface area, KNP $-23.5 \%$ ).

Being situated at the Finnish-Russian border and possessing large areas of intact old-growth boreal forests, these PAs are of global value as key components of conserved ecosystems native to the Green Belt of Fennoscandia (Sazonov, 1997, 2015). KNR is a part of the Finnish-Russian Friendship Nature Reserve. Both PAs are incorporated in the UNESCO Metsola Biosphere Reserve (UNESCO, 2020b). Metsola was established in 2017 within a project of the UNESCO Man and the Biosphere
Programme. According to that, a biosphere reserve is a «Science for Sustainability support site» being a special place for testing interdisciplinary approaches to understanding and managing changes and interactions between social and ecological systems, including conflict prevention and management of biodiversity (UNESCO, 2020a).

Field data were gathered in 2015-2019 (June 2015; July 2016, 2018, 2019; August 2017) by transect (Sazonov, 1997) and point (Bogolyubov, 1996) count techniques. The transect method was applied to enable a comparison between our data and the data collected in 1980-1990s by Sazonov (1997), whose publication is very informative and also presents the exact routs of surveys which could be repeated. Sazonov (1997) used the transect method with routes covered all types of habitats. Minimal data processing excluded any species-specific coefficients, corrections or any other manipulations, and all available data represented «raw» material. Our transect counts, as well as Sazonov's (1997) counts, were conducted by the «route accounting unlimited bandwidth detection». Five transects copied the routes of Sazonov (1997) and 15 transects were freely chosen. We repeated counts in transects 2-3 times per season.

The average population density was calculated according to the average detection range of the birds. The abundance limits in the Electronic Supplement were selected from the density of every species along every route inside the PAs. The population density of every species was estimated with the following formula (Romanov \& Maltsev, 2005):

$$
N=\frac{X}{(L \times h)}
$$

where $\mathrm{N}$ - the population density, individuals/ $\mathrm{km}^{2} ; \mathrm{X}$ - the average number of individuals; $\mathrm{h}$ the average detection range, $\mathrm{km} ; \mathrm{L}$ - the length of the route, $\mathrm{km}$.

Point counts were used for a more precise assessment of changes in bird numbers depending on the distance to the source of impact (in our case, the edge of an adjacent logged area) with the chosen models (see below). We used two parameters of bird numbers: (1) the number of individuals and (2) the number of species. Model circular transects were marked out within KNR and KNP, and in adjacent areas recently logged through checker-wise series of fellings. The points for the counts were evenly distributed along each transect, with 250 $300 \mathrm{~m}$ spacing. Observation at each point lasted 5 min. Each transect (both in transect counts as such and in point counts) was $5-10 \mathrm{~km}$ long. 


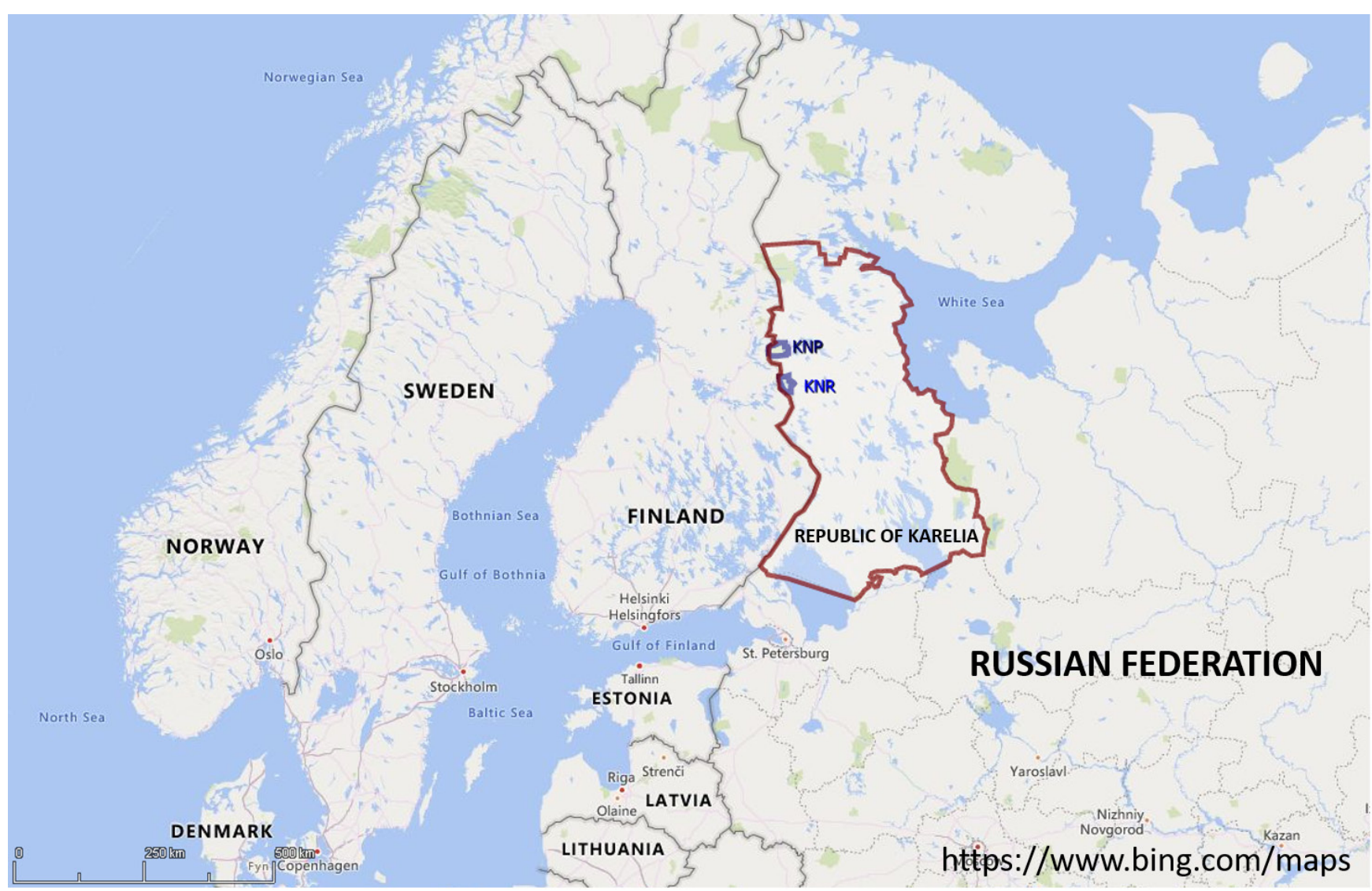

Fig. 1. Location of the studied areas in Russian Karelia and Europe. Designations: KNP - Kalevala National Park; KNR - Kostomuksha State Nature Reserve.

To analyse how recently logged areas adjoining the PAs might have affected the avifauna of KNR and KNP we estimated the frequency of occurrence of birds of various species along transects at various distances from the PA-bordering logged areas. In our study, the model type of «recently logged areas» was a site harvested within the past five years. Surveys spanned 0 to $12 \mathrm{~km}$ from the nearest edge of the model-type logged area closest to the PA border and directly into the PA. Bird encounters were referenced to the geographic co-ordinate system. The smallest distances from observation points to the nearest edge of a logged area were calculated by using geographic co-ordinates and the haversine formula.

Species names and taxonomic affiliations are cited according to the Bird Checklists of the World (Avibase, 2019). Their classification into faunistic groups is present according to Sazonov (2012). We used the classification into faunistic groups distinguished by Sazonov (2012) to enable a comparison between our data and the data collected by the researchers who have worked in KNR and the planned KNP area in the past (Sazonov, 1997). Three faunistic groups (northern species, widespread species and southern species) were selected according to the origin of the species (Sazonov, 2012). The other three groups (target groups) were selected to verify the hypothesis about a logging influence on the birds in the studied ecosystems. Two of these groups (boreal species and open-site species) conform to the groups distinguished by Sazonov (2012), and one group (background species) includes the most numerous taxa. Background bird species are all bird species with a density more than one individual per unit $\left(1 \mathrm{~km}^{2}\right)$ (Tsybulin, 2009).

Statistical analysis was done in $\mathrm{R}$ environment v. 3.6.1 (R Core Team, 2019) and using Microsoft Excel software. We compared the level of diversity and evenness in the surveyed communities utilising the Shannon and Simpson indices. Data distribution within groups was tested for normality by the Anderson-Darling test (package «nortest» v. 1.0-4 (Ligges \& Gross, 2015)). The statistical significance of average diversity differences between communities was measured by the Student's $t$-test (Microsoft Excel software). The similarity between the communities was estimated by the Jaccard index. Pairwise correlations were calculated using the Spearman rank correlation coefficient (package «stats», part of $\mathrm{R}$ v.3.6.2, by R Core Team, 2019). 


\section{Results and Discussion}

Species composition and abundance parameters of birds in Kostomuksha State Nature Reserve and Kalevala National Park

Our surveys inside KNR and in its adjacent areas yielded records 1279 individuals of 114 bird species (Electronic Supplement) belonging to 38 families and 12 orders. Among these, 109 species (106 breeding or allegedly breeding) were encountered only inside KNR, and two species (both of them are breeding birds: Motacilla flava Linnaeus, 1758 and Oenanthe oenanthe (Linnaeus, 1758)) were found only in nearby logged areas. Three other breeding species (Columba livia Gmelin, 1789, Phylloscopus sibilatrix (Bechstein, 1793), and Passer domesticus (Linnaeus, 1758)) were reported from Kostomuksha town suburbs administratively belonging to the Protected Area.

Columba livia and Passer domesticus are typically synanthropic birds. Their presence within KNR is unlikely, although not ruled out, given the vicinity of the town. Phylloscopus sibilatrix forms a low-density (not more than 1-2 pairs/ $\mathrm{km}^{2}$ ) population in Kostomuksha's green belt, in the best-suited habitats in the study period. Being in the northern periphery of the species' range, the area contains low numbers of these birds, fluctuating substantially through the years. Phylloscopus sibilatrix breeds in sparse and tall pine-birch (Pinus sylvestris, Betula sp.) forests with scarce undergrowth which occur in the town's green belt but not in the KNR main area. It is probably because of the lack of good breeding habitats that $P$. sibilatrix was not encountered inside KNR.

Encounters of species such as Anas platyrhynchos Linnaeus, 1758, Chroicocephalus ridibundus Linnaeus, 1766, and Larus canus Linnaeus, 1758 inside KNR were singular, but their numbers were much higher in the town. Up to several broods of $A$. platyrhynchos aggregate near a small lake, where local people come to feed them. Chroicocephalus ridibundus and L. canus form larger aggregations of up to several dozens of birds on Lake Kontokkijarvi. Sightings of Sturnus vulgaris Linnaeus, 1758 are rare both in the town and in KNR.

Surveys in KNP and its surroundings in 2015-2019 yielded records 982 individuals of 87 bird species (Electronic Supplement) belonging to 31 families and 11 orders. In the KNP, the breeding was confirmed or alleged for all these species, excluding Stercorarius pomarinus (Temminck, 1815), a bird vagrant in KNP. Of these, 85 species were encountered inside the PA, and two species, as in the case of KNR, were sighted only in logged areas adjoining the PA: Motacilla flava and Oenanthe oenanthe.

The Electronic Supplement reports data from the surveys carried out in 2015-2019 similarly to Sazonov (1997) to enable a comparison between new records and the data gathered more than 20 years ago. Similarly to Sazonov's studies, the bird population densities were averaged over the entire landscape (the type of terrain), including mires and small water bodies.

Surveys in the logged areas closest to the PAs detected the breeding of birds typical for open habitats, such as Oenanthe oenanthe, Saxicola rubetra (Linnaeus, 1758), Motacilla alba Linnaeus, 1758, and Motacilla flava. Oenanthe oenanthe and M. flava have not been encountered inside the PAs. But near the KNR and KNP their breeding suggests that these birds may be visiting the PAs, too.

In 2015-2019, some species were not observed in KNR and KNP, first of all, some semiaquatic birds, as well as some diurnal and nocturnal raptors, which, judging by earlier reports (Danilov et al., 1977; Adrianova et al., 1990; Rajasärkkä \& Virolainen, 1995; Sazonov, 1997, 2015; Zimin \& Sazonov, 1997; Gromtsev, 2002; Rajasärkkä, 2004; Preobrazhenskaya, 2015), were rare or very rare breeders in and around the PAs. The status of the previously observed species has not necessarily changed. Possibly, these birds did not occur in our surveys because of their low numbers and irregular breeding. Further surveys are needed to get updates on the status of such species and their breeding number in the PAs.

Rare bird species in Kostomuksha State Nature Reserve and Kalevala National Park

By surveying the PAs in 2015-2019, we recorded ten species (subspecies) listed in the Red Data Book of the Republic of Karelia (2007), including five of them included in the Red Data Book of the Russian Federation (2001) (Electronic Supplement). For most of these species, breeding is alleged in the PAs (regular encounters during the breeding season, sightings of birds displaying breeding behaviour). For some of them, it is confirmed (occupied nests, broods of recently fledged chicks). Thus, on 4 July 2019, we found an occupied nest of Pandion haliaetus Linnaeus, 1758 on the top of a dead standing pine tree in KNP. Both parents were feeding the offspring.

A brood of Grus grus Linnaeus, 1758 with two recently fledged chicks was found in the periphery 
of KNR on 7 July 2018. In July 2019, a G. grus pair, demonstrating breeding behaviour, was observed in KNP. Breeding pairs of Larus fuscus Linnaeus, 1758 were noticed on Lake Sudno in KNP. Breeding of Phoenicurus phoenicurus Linnaeus, 1758 has been repeatedly detected in both PAs.

It is also interesting to look at some other species that are not included in the Red Data Books of either Russia or Karelia but are rare and in need of monitoring and protection. For instance Cygnus cygnus Linnaeus, 1758 is supposed to breed in KNR and KNP. Several times in both PAs we observed C. cygnus with young individuals. Besides, KNR is a breeding site for Anser fabalis fabalis (Latham, 1787), a subspecies whose population has been declined in the past several decades throughout its range (Marjakangas et al., 2015). In 2015, in late June, we observed here a brood of Anser fabalis fabalis with goslings about half the size of an adult. Since the PAs are part of the Russian-Finnish Nature Reserve, it would be relevant to mention that we registered there 44 species included in the 2019 Red List of Finnish Species (Hyvärinen et al., 2019) (Electronic Supplement). Rare species, especially specialists, deserve particular attention because whereas generalist species can be tolerated to transformed habitats and even benefit from them. Rare specialist species can be especially vulnerable to habitat loss or fragmentation (e.g. Davies et al., 2004; Laurance \& Vasconcelos, 2009; Lebbin et al., 2010; Morante-Filho et al., 2015).

Comparative analysis of avifauna in Kostomuksha State Nature Reserve and Kalevala National Park at present and in the past

The species composition of bird populations was similar between KNR and KNP (Electronic
Supplement), i.e. the Jaccard index was 0.76 . The similarity in the species composition and number of birds between these PAs was corroborated also by the Shannon Diversity Index $(S H D I)$, which was 3.70 for $\mathrm{KNR}$ and 3.39 for $\mathrm{KNP}(t=1.19, t$ $t a b .=1.97, t<t t a b$., i.e. differences are insignificant). Similar values were also obtained for the Simpson Dominance Index $(D)$, which measures community evenness numerically $(D=0.03$ for KNR and $D=0.04$ for KNP).

Thus, data from 2015-2019 give no reason to speak of any significant distinctions in the composition of avifauna between KNR and KNP previously reported by Sazonov (2015). Analysing the composition of faunistic groups in the PAs, Sazonov (2015) noted that KNP has a higher proportion of northern species and a lower proportion of southern species than KNR. These differences, however, were relatively minor: 43 northern species (39.1\% of the avifauna) and 23 southern species $(22.3 \%)$ in KNR, and 46 northern species (41.1\%) and 21 southern species $(18.7 \%)$ in KNP.

Our data on the distribution of species in the PAs among the faunistic groups distinguished by Sazonov $(2012,2015)$ are given in Table 1. Among the species breeding or allegedly breeding in the PAs, northern species account for $31-35 \%$, widespread species for $42 \%$, and southern species for $24-27 \%$. A similar ratio is observed for regularly breeding species taken alone, too. This distribution pattern is generally typical in boreal bird faunas (Sazonov, 2015). It would be premature to proclaim there is a significant difference between the PAs on this parameter since a more complete faunogenetic analysis requires a clarification of the status of the species that are now only alleged to breed in the conservation areas.

Table 1. The shares of species belonging to different faunistic groups in Kostomuksha State Nature Reserve (KNR) and Kalevala National Park (KNP), \%

\begin{tabular}{|l|c|c|c|c|}
\hline \multirow{2}{*}{ Faunistic groups of birds } & \multicolumn{2}{c|}{ KNR } & \multicolumn{2}{c|}{ KNP } \\
\cline { 2 - 5 } & 1 & 2 & 1 & 2 \\
\hline Northern species: northern-middle taiga, subarctic and arctic & 39.1 & 34.9 & 41.1 & 31.4 \\
\hline Widespread species: belonging to arboreal Palearctic fauna, and azonal & 40.0 & 41.5 & 40.2 & 41.9 \\
\hline $\begin{array}{l}\text { Southern species: affiliated with European broadleaved and Far Eastern } \\
\text { coniferous and broadleaved forests, Mediterranean }\end{array}$ & 20.9 & 23.6 & 18.7 & 26.7 \\
\hline Number of breeding or allegedly breeding species & 110 & 106 & 112 & 86 \\
\hline
\end{tabular}

Note: 1 - breeding and allegedly breeding species (Sazonov, 1997), 2 - breeding and allegedly breeding species (our data from 2015-2019). 
By judging the data of 1980-1990 (Sazonov, 1997), in the PAs in the latest decades, a tendency has been for a decline in the proportion of northern species and a rise in the proportion of southern species (Table 1). Also, earlier surveys in KNR recorded higher numbers of boreal birds (e.g. Tetrao urogallus Linnaeus, 1758; Dryocopus martius (Linnaeus, 1758), Picoides tridactylus (Linnaeus, 1758), Perisoreus infaustus Linnaeus, 1758, Poecile cinctus Boddaert, 1783, Bombycilla garrulus (Linnaeus, 1758), Emberiza rustica Pallas, 1776). In the earlier surveys, higher breeding densities were observed even among such vulnerable boreal species as $\mathrm{Ga}$ via arctica (Linnaeus, 1758), Cygnus cygnus, Anser fabalis, Bucephala clangula (Linnaeus, 1758), and Mergus merganser Linnaeus, 1758. None of these species had high numbers in our surveys (Electronic Supplement). On the contrary, almost all of them demonstrated a low population density. In KNP, some increase in breeding density was detected in 2019 for the boreal species Fringilla montifringilla Linnaeus, 1758 and Emberiza rustica, i.e. 5.1 pairs/ $\mathrm{km}^{2}$ and 2.7 pairs $/ \mathrm{km}^{2}$, respectively. This is notably higher than their annual breeding density averaged over our study period (1.5 pairs $/ \mathrm{km}^{2}$ and 0.2 pairs/ $\mathrm{km}^{2}$, respectively); but it is still lower than Sazonov (1997) reported: $13.5-41.7$ pairs $/ \mathrm{km}^{2}$ and 2.8 12.5 pairs $/ \mathrm{km}^{2}$, respectively.

Thus, our data corroborate the conclusions about an ongoing species turnover. Researchers working in boreal landscapes of Northwest Russia have noted a reduction in the abundance of northern species, including boreal specialists, and their replacement by birds of southern latitudes. The latter lack the full set of adaptations to living in the north, first of all, to the reduced duration of the season suitable for breeding, creating risks for the stability of northern communities (Sazonov et al., 2002; Hokhlova \& Artemiev, 2007; Danilov, 2010; Khokhlova \& Artemiev, 2011).

Importantly, the decrease in number of northern species and increase in number of southern species associated with northward range shifts and density shifts in boreal landscapes have been also described in different northern regions (Lindström et al., 2013; Virkkala \& Lehikoinen, 2014, 2017; Lehikoinen \& Virkkala, 2016; Fraixedas et al., 2017; Virkkala et al., 2018). For instance, in Finland latitudinal northward shifts of the northern range borders in both southern and northern species were found. And for southern species, it was more pronounced and confirmed (Brommer et al., 2012). Later, climate-induced density northward shifts of species were described, although such shifts were faster in northern birds than in southern ones (Virkkala \& Lehikoinen, 2014). The researchers also expressed concern that a high bird species turnover observed in northern Europe may affect the functional diversity of species communities (e.g. Virkkala \& Lehikoinen, 2017).

Considering that the same process is happening in many boreal landscapes, it may partially reflect the global species abundance trends (EBCC, 2019) induced by a combined action of many factors not only in breeding areas, but also in overwintering grounds and along flyways. Indeed, similar processes are observed in many studied communities all around the world. And the main reason for them considers to be the ongoing climate warming (Parmesan, 2006; Devictor et al., 2008, 2012; Jiguet et al., 2010; Chen et al., 2011; Lindström et al., 2013; Roth et al., 2014; Lehikoinen \& Virkkala, 2016; Virkkala \& Lehikoinen, 2017; Brotons et al., 2019; Yang et al., 2020).

The additional reason of such changes might be the increasing human pressure on ecosystems, such as agricultural land-use, habitat disturbance, shrinking of old-growth forests, and expansion of logged areas, habitat fragmentation, and habitat loss (e.g. Bowler et al., 2018; Yalcin \& Leroux, 2018; Flesch, 2019). Particularly, in northern regions, disturbed habitats may not simply lose the properties required for them to be inhabited by typical boreal species, but also turn into ecological channels for the northwards expansion of species associated with broadleaved forests (Zimin, 2001).

In this light, the role of PAs may be even more appreciated. Obviously, the influence of climate change and its possible effects on the bird fauna spreads even on large pristine nature reserves (Langdon \& Lawler, 2015; Virkkala et al., 2018). Although in boreal PAs birds also shift northwards in the warming climate, and PAs can be not so efficient in preventing the climate-induced decline of migrants, the PAs are still successful in preserving resident bird species (Virkkala et al., 2018). Moreover, the size of PAs had a positive effect on the trends of residents (Virkkala et al., 2018), that increases the value of PAs like KNR and KNP. There is some evidence that PAs are really important for supporting the communities of northern species. Nevertheless, these communities are still shifting both inside and outside of PAs that requires proper conservation measures (Santangeli et al., 2017).

Assessment of nearby logged area's effects on avifauna in the Protected Areas

The most typical species inhabiting logged areas near KNR and KNP were birds associated 
with open habitats: Saxicola rubetra, Motacilla flava, and Oenanthe oenanthe. Saxicola rubetra and $O$. oenanthe bred in nearly every large logged area in the study area. Motacilla flava was not so frequent. As a rule, only one pair of this species was spotted in the surroundings of each PA per season. As mentioned above, M. flava and O. oenanthe were encountered in logged areas only, with no records from inside the PAs. Saxicola rubetra had a higher density in logged areas but reached also into the PAs periphery.

The cases of an increase in bird species diversity immediately after some anthropogenic impact, including habitat transformation and habitat fragmentation, have been noticed under different conditions and in different countries (e.g. Azevedo-Ramos et al., 2006; Kurhinen et al., 2009; Makarova \& Manukov, 2016; Lapshin et al., 2010). At the same time, it should be taken into account that this may be a result of so-called pseudo-enrichment of species diversity, which, as noted by Kurhinen et al. (2009), corresponds to the «intermediate violation hypothesis» (Connell, 1977). According to this hypothesis, the violation of the biocenosis at the initial stages may contribute to a temporal increase in its species diversity but subsequently threatens to reduce the abundance of specialised species. Similarly, when taiga ecosystems change against the background of an increase in species diversity due to species of open habitats, a decrease in the proportion of typical boreal species may occur. This again brings us to the problem of the species turnover in taiga fauna.

Besides that, the initial increase in diversity after anthropogenic impact can be followed by a contraction, because the remaining habitats may become insufficient for the increased abundance or an increased number of species. Moreover, invasion of non-forest bird species may increase competition for resources as well as parasite load, which later may reduce the reproductive success and viability of populations (Barrantes et al., 2016).

In the case of our research, calculations with the total data pool revealed no significant correlation between the number of species (Spearman rank correlation: $S=1129900$, rho $=0.072$, $p=0.32)$ or total bird population density $(S=$ 1225800 , rho $=-0.007, p=0.92)$ and the distance to the edge of the nearest logged area. However, if the bird number of different faunistic groups (Electronic Supplement) was analysed separately, an inverse correlation was found between the abundance and the number of southern species and the distance to the edge of the nearest logged area (Table 2). In other words, both the number of southern species and their total abundance were higher closer to logged areas. The effect of the vicinity of the logged areas on the number of species and abundance of northern birds and widespread species was insignificant (Table 2).

By verifying the working hypothesis using the survey data, we did not find the expected negative effect of a logged area's vicinity on the numbers of boreal species (Table 2). Its effect on the number of background species (Anthus trivialis (Linnaeus, 1758), Regulus regulus (Linnaeus, 1758), Poecile montanus Conrad von Baldenstein, 1827, Fringilla coelebs Linnaeus, 1758, Fringilla montifringilla) was supposed to be neutral. But a weak negative correlation was detected between their abundance and distance to the logged area (Table 2 ). The assumption about a positive effect of the logged area's vicinity on the number of birds associated with open habitats was confirmed (Table 2). Thus, judging by our data, boreal birds inhabiting the PAs are tolerant to the presence of logged areas around the PAs. The most probable explanations for that are the large size of the PAs, substantial areas of habitats suitable for living and breeding, and low human pressure inside the PAs.

Table 2. Spearman rank correlation for the studied parameters and the distance to the nearest logged area's edge

\begin{tabular}{|c|c|c|c|c|c|}
\hline Supracategory & Category & Parameter & $S$ & Rho & $p$ \\
\hline \multirow{6}{*}{ Faunistic groups } & \multirow{2}{*}{ Northern species } & Number of species & 6856726 & -0.0375 & 0.4895 \\
\hline & & Number of individuals & 7068455 & -0.0696 & 0.1999 \\
\hline & \multirow{2}{*}{ Widespread species } & Number of species & 6278986 & 0.0499 & 0.3585 \\
\hline & & Number of individuals & 6159720 & 0.0679 & 0.2109 \\
\hline & \multirow{2}{*}{ Southern species } & Number of species & 7587333 & -0.1481 & $0.0061^{*}$ \\
\hline & & Number of individuals & 7683667 & -0.1627 & $0.0025^{*}$ \\
\hline \multirow{6}{*}{ Target groups } & \multirow{2}{*}{ Boreal species } & Number of species & 6869476 & -0.0395 & 0.4675 \\
\hline & & Number of individuals & 7052896 & -0.0672 & 0.2156 \\
\hline & \multirow{2}{*}{ Background species } & Number of species & 7257675 & -0.0982 & 0.0701 \\
\hline & & Number of individuals & 7482211 & -0.1322 & $0.0146^{*}$ \\
\hline & \multirow{2}{*}{ Open-site species } & Number of species & 7436730 & -0.1253 & $0.0206^{*}$ \\
\hline & & Number of individuals & 7434701 & -0.1250 & $0.0209^{*}$ \\
\hline
\end{tabular}


The negative correlation between the abundance of background species and distance to a logged area is also quite explicable, given that inner parts of the PAs mainly have climax taiga communities with less diverse habitats. Compared to these monotonous climax habitats, the more diverse sites in the PA periphery, with a larger proportion of habitats not yet in the final stages of the succession, and with a higher contribution of edge habitats, attract many bird species, including the most abundant ones.

The positive effect of logging on the abundance of birds associated with open habitats is not surprising either. Moreover, some species appeared around the PAs exactly owing to the presence of logged areas. Apparently, the lack of open habitats inside the PAs prevents to dispersing of open site species into inner parts of them. However, there are several demolished houses and engineering constructions inside both PAs, but habitats in their surroundings are suboptimal for open site species. So, it cannot be ruled out, that as the logged area around the PAs expands, and the number of species associated with open habitats increases accordingly, some of them may disperse into such transformed habitats in the PAs. Whether or not this increase would induce critical changes in the native avifauna is still a question. As now the threat appears minor, further monitoring of the bird population around the PAs is needed to be able to predict the situation for the PA fauna and secure timely response to potential risks. In the light of this fact, it is even more important, that an increase in number of birds affiliated with open habitats might be also partially caused by global warming. The climate change-induced shifts in bird communities must be timely monitored inside PAs as well as outside them.

For example, taking a pair of typical boreal birds belonging to the same family (Tetrastes bonasia (Linnaeus, 1758) and Tetrao urogallus) and differing in resistance to human pressure, we estimated the smallest distance to a recently logged area where these birds were encountered in the PAs. The occurrence of Tetrastes bonasia in the PAs started $270 \mathrm{~m}$ away from recently logged areas, whereas $T$. urogallus did not occur until $2 \mathrm{~km}$ away from them. However, in our study, no further correlation was detected between the abundance of these birds and distance to the logged area (Spearman rank correlation: $S=5920200$, rho $=0.104, p=0.06$, and $S=6236100$, rho $=0.056, p$ $=0.30$ for $T$. bonasia and T. urogallus, respectively). Nonetheless, in northern taiga forests of Karelia, the distribution of T. urogallus has been previously demonstrated its correlation with the proportion of forest cover and the distribution of mature and over-mature coniferous stands (Danilov, 2010). Here, the species biology, specific movements of individuals among habitats, should be taken into account. In particular, when the mating period ends, T. urogallus retreats to «hideaways» in the forests. By the late summer, its females with broods occupy the most food-rich locations, and the distribution of birds among habitats evens out (Danilov, 2010). A more comprehensive analysis of the remote effect of logging on T. urogallus abundance in undisturbed areas certainly requires gathering more data for different stages in the annual cycle of these bird species.

Among Galliformes, the highest tolerance to logged areas in the surroundings was demonstrated by Lyrurus tetrix Linnaeus, 1758, a widespread species. Individuals of this species were encountered at the very edge of logged areas. The association of these birds with disturbed areas was highlighted in previous studies as well. In Karelia, the abundance of $L$. tetrix positively correlated with the proportion of logged areas and young forest stands, while it correlated negatively with the proportion of old-growth forests (Danilov, 2010).

Thus logged areas are a factor attracting southern birds and widespread species to the PAs periphery. On the other hand, the extensiveness of KNR and KNP areas mitigates the effects of nearby logged areas on the abundance of northern species, which would have otherwise been more pronounced.

\section{Conclusions}

In 2015-2019 surveys, the species composition of the bird population between KNR and KNP was similar and typical for boreal bird faunas. The trend observed lately in the studied PAs is a decline in the proportion of northern species and an increase in the proportion of southern species. Presumably, the most probable reason of such shifts in boreal ecosystems is global warming. Against this background, the anthropogenic transformation of habitats may intensify changes in the species composition. Considering that similar processes are happening in many boreal landscapes, including PAs, they may partially reflect the global species abundance trends induced by the climate change, human impact and combined action of other factors not only in breeding areas but also along flyways and in wintering sites. These issues need to be studied in more detail.

Assessing the effect of logged areas adjoining to PAs, we observed that among the three bird species dwelling in logged areas around KNR and KNP (Saxicola rubetra, Motacilla flava, and Oenanthe oenanthe), only one ( $S$. rubetra) was encountered in 
peripheral areas within the PAs. However, it cannot be ruled out, that as the logged area around the PAs expands, the number of species associated with open habitats also increases. Some of them may disperse into the transformed habitats available in the PAs. Whether or not this would induce critical changes in the native avifauna is still a question. The threat appears minor so far, but in the light of ongoing climate change and habitat transformation, further monitoring of the bird communities around the PAs is needed to be able to predict the situation for the PA fauna and secure timely response if risks are identified.

At present, the effect of logged area's vicinity is most pronounced for the abundance and composition of southern species, which usually favour disturbed habitats and avoid the «wildest» parts of the taiga. A similar tendency among widespread species is evidenced by the negative correlation between their abundance and distance to the logged area's edge. It would be logical to assume that continuing logging near the PAs would enlarge the proportion of widespread species and promote the species turnover inside the PAs as well, at least in their marginal parts.

Analysis of data obtained in 2015-2019 revealed no negative impact of logged areas' vicinity on the abundance of boreal bird species inside the surveyed PAs. The resistance of the conservation areas to logging around them is most probably due to their substantial size, and strict limitations on human activities in the area. The latter proves once again how important it is to preserve large pristine forest stands and PAs (Virkkala et al., 2014; Santangeli et al., 2017; Lehikoinen et al., 2018), that should be prioritised by the nations possessing such natural areas (Gorshkov \& Makarieva, 1998; Makarieva \& Gorshkov, 2012).

In conclusion, we can state that both climate change and logging change the boreal bird communities towards domination of southern species. Thus, anthropogenic pressures are shaping bird communities, which can influence both PAs and areas outside of them.

\section{Acknowledgements}

We are deeply grateful to S.V. Tarkhov (Director of the Kostomukshsa State Nature Reserve, Russia) as well as Yu.A. Krasovsky, N.S. Sikkilä, and I.S. Gaidysh for their help in organising the field work. We also thank O.S. Kislova for the translation of the manuscript into English. The studies were carried out under contracts with the Kostomukshsa State Nature Reserve administration and co-financed by the federal budget under state order to KarRC RAS (0218-20190080). The final stage of the work was supported by the Russian Foundation for Basic Research (grant № 18-05-00646 and № 18-44-100008).

\section{Supporting Information}

The full dataset with 118 bird species (Electronic Supplement: Bird species, faunistic and target groups, conservation status, and abundance parameters averaged over the entire area of the surveyed type of landscape in Kostomuksha State Nature Reserve (KNR) and Kalevala National Park (KNP)), may be found in the Supporting Information here.

\section{References}

Adrianova O.V., Malenkov V.L., Malenkova A.Yu., Pozdnyakov S.A. 1990. Terrestrial vertebrates of the Kostomuksha State Nature Reserve. In: Terrestrial vertebrates in nature reserves of the North of the European part of the RSFSR. Moscow: Central Research Laboratory of the Hunting and Nature Reserves of the Russian Federation. P. 10-28. [In Russian]

Anker-Nilssen T. 2006. The avifaunal value of the Lofoten Islands in a World Heritage perspective. NINA Report 201: 1-23.

Avibase. 2019. Bird Checklists of the World. Europe. Available from https://avibase.bsc-eoc.org/checklist. jsp?region $=$ EUR

Azevedo-Ramos C., de Carvalho O.Jr., do Amaral B.D. 2006. Short-term effects of reduced-impact logging on eastern Amazon fauna. Forest Ecology and Management 232(1-3): 26-35. DOI: 10.1016/j.foreco.2006.05.025

Barrantes G., Ocampo D., Ramírez-Fernández J.D., Fuchs E.J. 2016. Effect of fragmentation on the Costa Rican dry forest avifauna. PeerJ 4: e2422. DOI: 10.7717/peerj.2422

Batt K.E. 2015. Species diversity of the bird fauna at the Barguzin reservation in summer. Altai Zoological Journal 9: 57-59. [In Russian]

Belik V.P. 2015. Materials to avifauna of the Pitsunda-Miusserskiy Nature Reserve and its vicinities. Ornithologia 39: 5-47. [In Russian]

Belik V.P. 2018. Avifauna of the Kabardino-Balkarian Nature Reserve in the Central Caucasus: composition, structure, distribution, population dynamics. Ornithologia 42: 104-121. [In Russian]

Bogolyubov A.S. 1996. Methods of counting birds: point counts. Moscow: Ekosistema. 9 p. [In Russian]

Bologov V.V., Sikkilä N.S. 2013. Square 36WUS4. Republic of Karelia, Kostomuksha State Nature Reserve. In: O.V. Voltzit, M.V. Kalyakin (Eds.): Fauna and Abundance of European Russia Birds. Vol. 1. Moscow: Fiton XXI. P. 150-151. [In Russian]

Bowler D.E., Heldbjerg H., Fox A.D., O’Hara R.B., Böhning-Gaese K. 2018. Disentangling the effects of multiple environmental drivers on population changes within communities. Journal of Animal Ecology 87(4): 1034 1045. DOI: 10.1111/1365-2656.12829

Brommer J., Lehikoinen A., Valkama J. 2012. The breeding ranges of Central European and Arctic bird species move poleward. PloS ONE 7 (9): e43648. DOI: 10.1371/journal.pone.0043648

Brotons L., Herrando S., Jiguet F., Lehikoinen A. 2019. Bird communities and climate change. In: P.O. Dunn, A.P. 
Møller (Eds.): Effects of climate change on birds. $2^{\text {nd }}$ edition. Oxford: Oxford University Press. 320 p. DOI: 10.1093/oso/9780198824268.003.0016

Butchart S.H.M., Walpole M., Collen B., van Strien A., Scharlemann J.P., Almond R.E., Baillie J.E., Bomhard B., Brown C., Bruno J., Carpenter K.E., Carr G.M., Chanson J., Chenery A.M., Csirke J., Davidson N.C., Dentener F., Foster M., Galli A., Galloway J.N., Genovesi P., Gregory R.D., Hockings M., Kapos V., Lamarque J.F., Leverington F., Loh J., McGeoch M.A., McRae L., Minasyan A. et al. 2010. Global biodiversity: indicators of recent declines. Science 328(5982): 1164-11168. DOI: 10.1126/science.1187512

Buzun V.A., Bolshakov A.A., Zatsarinny I.V., Bychkov Yu.M., Buzun M.V., Shavrina U.Yu., Gribova M.O. 2018. On the avifauna of the Pasvik Reserve. Russian Journal of Ornithology 27(1706): 5967-5986. [In Russian]

Chen I.C., Hill J.K., Ohlemüller R., Roy D.B., Thomas C.D. 2011. Rapid range shifts of species associated with high levels of climate warming. Science 333(6045): 1024 1026. DOI: $10.1126 /$ science. 1206432

Connell J.H. 1977. Diversity in tropical rain forests and coral reefs. Science 199(4335): 1302-1310. DOI: 10.1126/ science.199.4335.1302

Czeszczewik D., Zub K., Stanski T., Sahel M., Kapusta A., Walankiewicz W. 2015. Effects of forest management on bird assemblages in the Bialowieza Forest, Poland. iForest 8(3): 377-385. DOI: 10.3832/ifor1212-007

Danilov P.I. (Ed.). 2010. Monitoring and conservation of biodiversity in taiga ecosystems of European North of Russia. Petrozavodsk: KarRC RAS. 310 p. [In Russian]

Danilov P.I., Zimin V.B., Ivanter T.V., Lapshin N.V., Markovsky V.A., Annenkov V.G. 1977. Faunistic review of terrestrial vertebrates. In: Biological resources of the Kostomuksha region, ways of development and protection. Petrozavodsk: Karelian Branch of the AS USSR. P. 109-127. [In Russian]

Davies K.F., Margules C.R., Lawrence J.F. 2004. A synergistic effect puts rare, specialized species at greater risk of extinction. Ecology 85(1): 265-271. DOI: 10.1890/03-0110

Devictor V., Julliard R., Couvet D., Jiguet F. 2008. Birds are tracking climate warming, but not fast enough. Proceedings of the Royal Society of London, Series B 275: 2743-2748. DOI: 10.1098/rspb.2008.0878

Devictor V., Van Swaay C., Brereton T., Brotons L., Chamberlain D., Heliölä J., Herrando S., Julliard R., Kuussaari M., Lindström Å., Reif J., Roy D.B., Schweiger O., Settele J., Stefanescu C., Van Strien A., Van Turnhout C., Vermouzek Z., WallisDeVries M., Wynhoff I., Jiguet F. 2012. Differences in the climatic debts of birds and butterflies at a continental scale. Nature Climate Change 2: 121-124. DOI: 10.1038/NCLIMATE1347

EBCC. 2019. European Bird Census Council. Available from https://www.ebcc.info/

Elts J., Leivits M., Luigujõe L., Väli Ü. 2019. Status and numbers of Estonian birds, 2013-2017. Hirundo 32(1): 1-39. [In Estonian]

Fetisov S.A. 2019. Results of inventory and monitoring of the avifauna of the Sebezhsky National Park (as of 2019). Russian Journal of Ornithology 28(1776): 2459-2492. [In Russian]
Flesch A.D. 2019. Patterns and drivers of long-term changes in breeding bird communities in a global biodiversity hotspot in Mexico. Diversity and Distributions 25(4): 499-513. DOI: 10.1111/ddi.12862

Fraixedas S. 2017. Bird populations in a changing world: implications for North European Conservation. Academic Dissertation. Helsinki: University of Helsinki. 60 p.

Fraixedas S., Lindén A., Meller K., Lindström Å., Keišs O., Kålås J.A., Husby M., Leivits A., Leivits M., Lehikoinen A. 2017. Substantial decline of Northern European peatland bird populations: Consequences of drainage. Biological Conservation 214: 223-232. DOI: 10.1016/j.biocon.2017.08.025

Garcia R.A., Cabeza M., Rahbek C., Araújo M.B., 2014. Multiple dimensions of climate change and their implications for biodiversity. Science 344(6183): 1247579. DOI: $10.1126 /$ science. 1247579

Gaston K.J., Jackson S.E., Cantu-Salazar L., Cruz-Pinon G. 2008. The ecological performance of protected areas. Annual Review of Ecology, Evolution, and Systematics 39: 93-113. DOI: 10.1146/annurev.ecolsys.39.110707.173529

Gillespie J. 2020. Protected Areas. In: J. Gillespie (Ed.): Protected Areas: A Legal Geography Approach. Cham: Palgrave Pivot. P. 13-27. DOI: 10.1007/978-3-030-40502-1 2

Gillingham P.K., Bradbury R.B., Roy D.B., Anderson B.J., Baxter J.M., Bourn N.A.D., Crick H.Q.P., Findon R.A., Fox R., Franco A., Hill J.K., Hodgson J.A., Holt A.R., Morecroft M.D., O’Hanlon N.J., Oliver T.H., Pearce-Higgins J.W., Procter D.A., Thomas J.A., Walker K.J., Walmsley C.A., Wilson R.J., Thomas C.D. 2015. The effectiveness of protected areas in the conservation of species with changing geographical ranges. Biological Journal of the Linnean Society 115(3): 707-717. DOI: 10.1111/bij.12506

Gluschenko Yu.N., Korobov D.V. 2015. New data on study of the fauna of the birds of Far Eastern Marine Reserve. Biodiversity and Environment of Far East Reserves 5: 22-45. [In Russian]

Gorshkov V.G., Makarieva A.M. 1998. Biotic regulation of the environment: the rationale for conservation and restoration of the natural biota on the territories of continental scale. In: Biotic regulation of the environment. Petrozavodsk: Petrozavodsk State University. P. 3-20. [In Russian]

Gromtsev A.N. 2000. Landscape ecology of taiga forests: theoretical and applied aspects. Petrozavodsk: KarRC RAS. 144 p. [In Russian]

Gromtsev A.N. (Ed.). 2002. Natural complexes, flora and fauna of the proposed Kalevala National Park. Helsinki: Finnish Environment Institute, Karelian Research Centre. 74 p. [In Russian]

Gromtsev A.N. 2009. Forests of Kostomukshsky Strict Nature Reserve: structure, dynamics, landscape patterns. Transactions of Karelian Research Centre of Russian Academy of Science 2: 71-78. [In Russian]

Hansen M.C., Potapov P.V., Moore R., Hancher M., Turubanova S.A., Tyukavina A., Thau D., Stehman S.V., Goetz S.J., Loveland T.R., Kommareddy A., Egorov A., Chini L., Justice C.O., Townshend J.R.G. 2013. High-Resolution Global Maps of 21st-Century Forest Cover Change. Science 342(6160): 850-853. DOI: 10.1126/science.1244693 
Hansen M.C., Potapov P.V., Moore R., Hancher M., Turubanova S.A., Tyukavina A., Thau D., Stehman S.V., Goetz S.J., Loveland T.R., Kommareddy A., Egorov A., Chini L., Justice C.O., Townshend J.R.G. 2019. Global Forest Change. Department of geographical sciences, University of Maryland. Available from http://earthenginepartners.appspot.com/science-2013-global-forest

Hasanova S.M. 2019. Current condition of avifauna Turyanchay reserve and annexed territories. Bulletin of Perm University. Biology 3: 54-57. [In Russian]

Helle P., Sulkava S., Mela M. 1983. Oulangan kansallispuiston ja sen lahialueiden pesimalinnustosto. Oulun yliopiston Oulangan biologisen aseman monisteita 5: 2-19.

Heller N.E., Zavaleta E.S. 2009. Biodiversity management in the face of climate change: A review of 22 years of recommendations. Biological Conservation 142(1): 14-32. DOI: 10.1016/j.biocon.2008.10.006

Hoffmann M., Hilton-Taylor C., Angulo A., Böhm M., Brooks T.M., Butchart S.H.M., Carpenter K.E., Chanson J., Collen B., Cox N.A., Darwall W.R.T., Dulvy N.K., Harrison L.R., Katariya V., Pollock C.M., Quader S., Richman N.I., Rodrigues A.S.L., Tognelli M.F., Vié J.-C., Aguiar J.M., Allen D.J., Allen G.R., Amori G., Ananjeva N.B., Andreone F., Andrew P., Ortiz A.L.A., Baillie J.E.M., Baldi R. et al. 2010. The impact of conservation on the status of the world's vertebrates. Science 330(6010): 1503-1509. DOI: $10.1126 /$ science. 1194442

Hokhlova T.Y., Artemiev A.V. 2007. The main results of the long-term ornithological monitoring in the zone of bird's area limits concentration in northwest Russia (Karelia, Zaonezhye). In: Dynamics of the birds'density in terrestrial landscapes. Moscow: A.N. Severtsov Institute of Ecology and Evolution. P. 60-74. [In Russian]

Huntley B., Collingham Y.C., Willis S.G., Green R.E. 2008. Potential impacts of climate change on European breeding birds. PLoS ONE 3(1): e1439. DOI: 10.1371/journal.pone.0001439

Huttunen A. 1992. Paanajarven suunnan linnustosta. Aureola 17(3-4): 109-112.

Hyvärinen E., Juslén A., Kemppainen E., Uddström A., Liukko U.M. (Eds.). 2019. The 2019 Red List of Finnish Species. Helsinki: Ympäristöministeriö, Suomen ympäristökeskus. 704 p.

Iovchenko N.P. 2011. Birds. In: N.P. Iovchenko (Ed.): Ecosystems of the Nature Reserve "Lakes Rakovye»: History and present state. St. Petersburg: St. Petersburg University Press. P. 76-189. [In Russian]

Jiguet F., Devictor V., Ottvall R., van Turnhout C., van der Jeugd H., Lindström Å. 2010. Bird population trends are linearly affected by climate change along species thermal ranges. Proceedings of the Royal Society of London, Series B 277: 3601-3618. DOI: 10.1098/rspb.2010.0796

Kashevarov B.N. 1998. The bird-game of the Kostomuksha region. In: Dynamics of game animals populations in Northern Europe. Proceedings of the $2^{\text {nd }}$ International Symposium. Petrozavodsk: Karelian Research Centre of RAS. P. 82-84.
Kashevarov B.N., Heikkilä R. 2003. Significance of International trans-boundary nature reserve Friendship in preserving game animals. In: Dynamics of game animals populations in Northern Europe. Proceedings of the $3^{\text {rd }}$ International Symposium. Petrozavodsk: Karelian Research Centre of RAS. P. 98-101.

Kashevarov B.N., Pozdnakov S.A. 1997. Tetraonidae of the Kostomuksha State Nature Reserve. In: Ecosystems, fauna and flora of the Finnish-Russian Nature Reserve Friendship. Helsinki: Finnish Environment Institute. P. 187-193. [In Russian]

Khokhlova T.Yu., Artemiev A.V. 2011. The importance of the Green Belt of Fennoscandia for the conservation of the bird fauna of the northern taiga of Europe. Transactions of Karelian Research Centre of Russian Academy of Science 2(12): 127-132. [In Russian]

Kolbin V.A. 2017. Ornitofauna Norsky reserve and country territories: modern overview. Amurian Zoological Journal 9(1): 49-71. [In Russian]

Kondratyev A.V., Glazov P.M., Zaynagutdinova E.M., Loshchagina J.A., Anisimov Yu.A., Pokrovskaya O.B. 2019. The current state and dynamics of bird fauna of Kolguev Island. Ornithologia 43: 24-44. [In Russian]

Kopij G. 2015. Breeding avifauna of the Special Protection Area Natura 2000 'Grądy Odrzańskie' in Czernica and Siechnice counties, Wrocław district (Poland). Acta Musei Silesiae, Scientiae Naturales 64(1): 51-67. DOI: 10.1515/cszma-2015-0007

Koshkin A.V. 2003. New in the avifauna of the Korgalzhyn Nature Reserve. Russian Journal of Ornithology 12(240): 1175-1177. [In Russian]

Kuleshova L.V., Korotkov V.N., Potapova N.A., Evstigneev O.I., Kozlenko A.B., Rusanova O.V. 1996. Complex analysis of postfire successions in forests of Kostomuksha State Nature Reserve. Bulletin of Moscow Society of Naturalists 101(4): 3-15. [In Russian]

Kurhinen J., Gromtsev A.N., Danilov P.I., Kryshen A.M., Linden H., Lindholm T. 2009. Features and significance of taiga corridors in East Fennoscandia. Transactions of Karelian Research Centre of Russian Academy of Science 2: 16-23. [In Russian]

Lampio T. 1945. Uhtuan etelä-, länsi- ja pohjoispuolen linnustosta. Ornis Fennica 2: 45-56.

Langdon J.G., Lawler J.J. 2015. Assessing the impacts of projected climate change on biodiversity in the protected areas of western North America. Ecosphere 6(5): 1-14. DOI: 10.1890/ES14-00400.1

Lapshin A.S., Spiridonov S.N., Rakhimov I.I. 2010. The modern condition of ornithological fauna in the fish factory ponds in the Republic of Mordovia. Bulletin of the Tatar State Humanitarian-Pedagogical University 2(20): 38-43. [In Russian]

Laurance W.F., Vasconcelos H.L. 2009. Deforestation and forest fragmentation in the amazon. In: Tropical Biology and Conservation Management. Vol. 2. Oxford: Eolss Publishers Co. Ltd. P. 23-29.

Lebbin D.J., Parr M.J., Fenwick G.H. 2010. The American bird conservancy guide to bird conservation. Chicago: University of Chicago Press. 456 p. 
Lehikoinen P., Santangeli A., Jaatinen K., Rajasärkkä A., Lehikoinen A. 2018. Protected areas act as a buffer against detrimental effects of climate change - Evidence from large-scale, long-term abundance data. Global Change Biology 25(1): 304-313. DOI: 10.1111/gcb.14461

Lehikoinen A., Virkkala R. 2016. North by north-west: climate change and directions of density shifts in birds. Global Change Biology 22(3): 1121-1129. DOI: 10.1111/gcb. 13150

Lehtonen L. 1943. Piirteitä Pohjois - ja Keski-Vienan linnustosta. Ornis Fennica 2-3: 33-58.

Ligges U., Gross J. 2015. Package 'nortest'v.1.0-4. Tests for Normality. Repository CRAN. $10 \mathrm{p}$.

Lindholm T., Heikkilä R., Heikkilä M. (Eds.). 1997. Ecosystems, fauna and flora of the Finnish-Russian Nature Reserve Friendship. Helsinki: Finnish Environment Institute. 364 p.

Lindström Å., Green M., Paulson G., Smith H.G., Devictor V. 2013. Rapid changes in bird community composition at multiple temporal and spatial scales in response to recent climate change. Ecography 36(3): 313-322. DOI: 10.1111/j.1600-0587.2012.07799.x

Makarieva A.M., Gorshkov V.G. 2012. Preservation of the Eurasian forest belt is a strategic task of Russia. Energy: economy, technology, ecology 9: 18-25. [In Russian]

Makarova M., Manukov Y. 2016. Assessment of the avifauna mixed forest on the territory of New Moscow. In: $A c$ tual problems of biological and chemical ecology. Moscow: Moscow State Regional University. P. 174-178. [In Russian]

Mäntyranta H. 2019. Forest sector in Finland. Available from https://forest.fi/article/forest-sector-in-finland/

Marja R., Nellis R. 2018. Perioodil 1984-2017 põllulindude arvukuse muutus Eestis ning selle seos põllumajanduse ja kiskjatega. Hirundo 31(1): 49-68. [In Estonian]

Marjakangas A., Alhainen M., Fox A.D., Heinicke T., Madsen J., Nilsson L., Rozenfeld S. 2015. International Single Species Action Plan for the Conservation of the Taiga Bean Goose Anser fabalis fabalis. Bonn: AEWA Technical Series 20. 88 p.

Merikallio E. 1921. Oulangan sedun ja Kaakkois - Kuolajarven linnusto. Acta Societatis pro Fauna et Flora Fennica 48(2): 1-168.

Merikallio E. 1958. Finnish birds, their distribution and numbers. Acta Societatis pro Fauna et Flora Fennica 5(2): 1-181.

Mjøs A.T. 2002. Review of older records and changes to the Norwegian bird list. Ornis Norvegica 25(2): 64-92.

Mnatsekanov R.A., Tilba P.A. 2015. Ornithofauna of the Utrish Reserve and its immediate surroundings. Russian Journal of Ornithology 24(1113): 754-763. [In Russian]

Morante-Filho J.C., Faria D., Mariano-Neto E., Rhodes J. 2015. Birds in anthropogenic landscapes: the responses of ecological groups to forest loss in the Brazilian Atlantic forest. PLoS ONE 10(6): e0128923. DOI: 10.1371/ journal.pone.0128923

Nacharkin G.A., Govorova E.A. 2018. The current state of the avifauna of the Sikhote-Alin Reserve. In: Modern problems of ornithology in Siberia and Central Asia.
Irkutsk: All-Russian Central Scientific and Technical Institute. P. 153-156. [In Russian]

Nankinov D.N., Nankinov N.D. 2013. About the avifauna of the Bulgarian Biosphere Reserve Parangalitsa. Russian Journal of Ornithology 22(872): 1093-1102. [In Russian]

Naumkin D.V. 2011. The avifauna of the subalpine meadows of the Basegi State Nature Reserve (Permsky Krai). Proceedings of the Mordovia State Nature Reserve 9: 106-114. [In Russian]

Naumkin D.V. 2013. Birds of the Kungur island pine-birch forest-steppe. Proceedings of the Basegi State Nature Reserve 3: 1-226. [In Russian]

Nellis R., Volke V. 2019. Metsalindude arvukuse muutused perioodil 1983-2018. Hirundo 32(1): 63-80. [In Estonian]

Olsen T.A., Mjølsnes K. 2007. Sjeldne fugler i Norge i 2005- Rapport fra Norsk sjeldenhetskomité for fugl (NSKF). Ornis Norvegica 30: 68-115. DOI: 10.15845/on.v30i0.178

Olsen T.A., Tveit B.O., Bunes V., Mjølsnes K.R. 2008. This is the 31st annual report from the Norwegian Rarities Committee (NSKF). Ornis Norvegica 31(1): 48-97.

Parmesan S. 2006. Ecological and evolutionary responses to recent climate change. Annual Review of Ecology, Evolution, and Systematics 37: 637-669. DOI: 10.1146/annurev.ecolsys.37.091305.110100

Pearce-Higgins J.W., Eglington S.M., Martay B., Chamberlain D.E. 2015. Drivers of climate change impacts on bird communities. Journal of Animal Ecology 84(4): 943-954. DOI: 10.1111/1365-2656.12364

Pimm S.L. 2008. Biodiversity: climate change or habitat loss - which will kill more species? Current Biology 18(3): 117-119. DOI: 10.1016/j.cub.2007.11.055

Preobrazhenskaya E.S. 2015. Winter bird populations in and around Kostomuksha State Nature Reserve during 2001-2013. Proceedings of the Kostomuksha State Nature Reserve 1: 153-160. [In Russian]

$\mathrm{R}$ Core Team. 2019. R: A language and environment for statistical computing. Vienna, Austria: R Foundation for Statistical Computing. Available from https://www.R-project.org/

Rajasärkkä A. 2004. Kainuun ja Vienan Karjalan metsä ja suolinnustot sekä niiden merkitys luontomatkailun kannalta. Alueelliset ympäristöjulkaisut 347: 47-126.

Rajasärkkä A., Virolainen E. 1990. Ystävyyden puiston linnusto. Väliraportti. Metsähallitus. 46 p.

Rajasärkkä A., Virolainen E. 1995. Ystävyyden luonnonsuojelualue - korpien kuiskintaa Kuhmon ja Kostamuksen saloilla. Linnut 30(4): 20-25.

Red Data Book of the Republic of Karelia. Petrozavodsk, 2007. 364 p. [In Russian]

Red Data Book of the Russian Federation. Animals. Moscow: Astrel, 2001. 862 p. [In Russian]

Romanov V.V., Maltsev I.V. 2005. Research methods of ecology of the terrestrial vertebrates: quantitative counts. Vladimir: Vladimir State University. 79 p. [In Russian]

Reznichenko S.M. 2015. Materials for avifauna of Karkarala National Park (Karaganda Oblast). Russian Journal of Ornithology 24(1224): 4427-4439. [In Russian] 
Rodrigues A.S.L., Andelman S.J., Bakarr M.I., Boitani L., Brooks T.M., Cowling R.M., Fishpool L.D.C., da Fonseca G.A.B., Gaston K.J., Hoffmann M., Long J.S., Marquet P.A., Pilgrim J.D., Pressey R.L., Schipper J., Sechrest W., Stuart S.N., Underhill L.G., Waller, R.W., Watts, M.E.J., Yan, X., 2004. Effectiveness of the global protected area network in representing species diversity. Nature 428: 640-643. DOI: $10.1038 /$ nature 02422

Roth T., Plattner M., Amrhein V. 2014. Plants, birds and butterflies: short-term responses of species communities to climate warming vary by taxon and with altitude. PLoS ONE 9(1): e82490. DOI: 10.1371/journal. pone. 0082490

Santangeli A., Rajasärkkä A., Lehikoinen A. 2017. Effects of high latitude protected areas on bird communities under rapid climate change. Global Change Biology 23(6): 2241-2249. DOI: $10.1111 / \mathrm{gcb} .13518$

Sazonov S.V. 1997. Ornithofauna of nature reserves and national parks of the Northern taiga in Eastern Fennoscandia and its zoogeographical analysis. Petrozavodsk: KarRC RAS. 116 p. [In Russian]

Sazonov S.V. 2012. Revised classification of the types of bird fauna and faunal groups in the west of Eurasian taiga. Transactions of Karelian Research Centre of Russian Academy of Science 1: 70-85. [In Russian]

Sazonov S.V. 2015. Birds of the Kostomuksha State Nature Reserve and adjacent territories. Proceedings of the Kostomuksha State Nature Reserve 1: 135-152. [In Russian]

Sazonov S.V., Artemjev A.V., Lapshn N.V., Hohlova T.Y. 2002. Natural complexes, flora and fauna of the proposed Kalevala National Park. Helsinki: Finnish Environment Institute, Karelian Research Centre. 74 p.

Segan D.B., Murray K.A., Watson J.E. 2016. A global assessment of current and future biodiversity vulnerability to habitat loss-climate change interactions. Global Ecology and Conservation 5: 12-21. DOI: 10.1016/j.gecco.2015.11.002

Simonov S.A., Matantseva M.V. 2017. A survey of the avifauna of the Kostomukshsky Strict Nature Reserve in 2015 and 2016. Transactions of Karelian Research Centre of Russian Academy of Science 4: 26-40. [In Russian]

Sokolov A.Yu. 2012. Changes in the avifauna of the «Forest on Vorskla» site of the Belogorye Reserve at the end of the 20th and beginning of the 21 st centuries. Russian Journal of Ornithology 21(776): 1676-1682. [In Russian]

Suomalainen P. 1952. Havantoja Oulangan - Paanajarven seudun ja kaakkois Sallan linnustosta. Ornis Fennica 29(3): 88-102.

Thomas C.D., Gillingham P.K. 2015. The performance of protected areas for biodiversity under climate change. Biological Journal of the Linnean Society 115(3): 718730. DOI: 10.1111/bij.12510

Thomas C., Cameron A., Green R., Bakkenes M., Beaumont L.J., Collingham Y.C., Erasmus B.F.N., de Siqueira M.F., Grainger A., Hannah L., Hughes L., Huntley B., van Jaarsveld A.S., Midgley G.F., Miles L., OrtegaHuerta M.A., Peterson A.T., Phillips O.L., Williams S.E. 2004. Extinction risk from climate change. Nature 427: 145-148. DOI: 10.1038/nature02121

Thomas C.D., Gillingham P.K., Bradbury R.B., Roy D.B., Anderson B.J., Baxter J.M., Bourn N.A.D., Crick H.Q.P., Findon R.A., Fox R., Hodgson J.A., Holt A.R., Morecroft M.D., O’Hanlon N.J., Oliver T.H., PearceHiggins J.W., Procter D.A., Thomas J.A., Walker K.J., Walmsley C.A., Wilson R.J., Hill J.K. 2012. Protected areas facilitate species' range expansions. Proceedings of the National Academy of Sciences of the United States of America 109(35): 14063-14068. DOI: 10.1073/pnas.1210251109

Tsybulin S.M. 2009. The birds of Altai: the spatiotemporal differentiation and the community structure and organisation. Novosibirsk: Nauka. 234 p. [In Russian]

UNESCO. 2020a. Biosphere Reserves - Learning Sites for Sustainable Development. Available from http://www. unesco.org/new/en/natural-sciences/environment/ecological-sciences/biosphere-reserves/

UNESCO. 2020b. Metsola Biosphere Reserve. Available from http://www.unesco.org/new/en/natural-sciences/ environment/ecological-sciences/biosphere-reserves/ europe-north-america/russian-federation/metsola/

Venter O., Fuller R.A., Segan D.B., Carwardine J., Brooks T., Butchart S.H.M., Marco M.D., Iwamura T., Joseph L., O’Grady D., Possingham H.P., Rondinini C., Smith R.J., Venter M., Watson J.E.M. 2014. Targeting global protected area expansion for imperiled biodiversity. PLoS Biology 12: e1001891. DOI: 10.1371/ journal.pbio.1001891

Virkkala R., Lehikoinen A. 2014. Patterns of climate-induced density shifts of species: poleward shifts faster in northern boreal birds than in southern birds. Global Change Biology 20(10): 2995-3003. DOI: 10.1111/gcb.12573

Virkkala R., Lehikoinen A. 2017. Birds on the move in the face of climate change: High species turnover in northern Europe. Ecology and Evolution 7(20): 8201-8209. DOI: $10.1002 /$ ece 3.3328

Virkkala R., Heikkinen R.K., Leikola N., Luoto M. 2008. Projected large-scale range reductions of northern-boreal land bird species due to climate change. Biological Conservation 141(5): 1343-1353. DOI: 10.1016/j. biocon.2008.03.007

Virkkala R., Pöyry J., Heikkinen R.K., Lehikoinen A., Valkama J. 2014. Protected areas alleviate climate change effects on northern bird species of conservation concern. Ecology and Evolution 4(15): 2991-3003. DOI: 10.1002/ece3.1162

Virkkala R., Rajasärkkä A., Heikkinen R.K., Kuusela S., Leikola N., Pöyry J. 2018. Birds in boreal protected areas shift northwards in the warming climate but show different rates of population decline. Biological Conservation 226: 271-279. DOI: 10.1016/j.biocon.2018.08.015

Virolainen E., Forsman D., Kostet J. 1992. Oulangan kansallispuiston linnut. Vantaa: Metsahallitus. 21 p.

Volkov S.L. 2016. Avifauna of the Vitimskiy Nature Reserve (the Irkutsk region): the composition, status, and habitat 
distribution of the species. Fauna of the Urals and Siberia 2: 34-65. [In Russian]

Volkov A.D., Gromtsev A.N., Erukov G.V., Karavaev V.N., Kolomytsev V.A., Kurkhinen Yu.P., Rukosuev S.I., Sazonov S.V., Shelekhov A.M. 1995. Landscape ecosystems of the west of the northern taiga (structure, dynamics). Petrozavodsk: KarRC RAS. 194 p. [In Russian]

Waaramäki T. 1945. Eräitä lintutietoja Kuusamosta vuosilta 1934-36, 1938-39 ja 1941-43. Ornis Fennica 22: 17-21.

Watson J.E.M., Dudley N., Segan D.B., Hockings M. 2014. The performance and potential of protected areas. $\mathrm{Na}$ ture 515: 67-73. DOI: 10.1038/nature13947

Yalcin S., Leroux S.J. 2018. An empirical test of the relative and combined effects of land-cover and climate change on local colonization and extinction. Global Change Biology 24(8): 3849-3861. DOI: 10.1111/gcb.14169

Yang X., Wang Y., Si X., Feng G. 2020. Species traits linked with range shifts of Chinese birds. Glob- al Ecology and Conservation 21: e00874. DOI: 10.1016/j.gecco.2019.e00874

Zimin V.B. 2001. Peculiarities of the distribution of birds in taiga of northwest Russia, real and false expansion (according to the ringed birds monitoring data). Transactions of Karelian Research Centre of Russian Academy of Science 2: 87-95. [In Russian]

Zimin V.B., Sazonov S.V. 1997. Birds of Kostomuksha. In: Ecosystems, fauna and flora of the Finnish-Russian Nature Reserve Friendship. Helsinki: Finnish Environment Institute. P. 157-186.

Zimin V.B., Sazonov S.V., Artemyev A.V., Lapshin N.V., Khokhlova T.Yu. 1998. The avifauna of protected areas and areas perspective for protection in the border zone of the Republic of Karelia. In: Biodiversity inventories and studies in the areas of Republic of Karelia bordering on Finland. Petrozavodsk: KarRC RAS. P. 116-131. [In Russian]

\title{
АНАЛИЗ СОВРЕМЕННОГО СОСТОЯНИЯ ОРНИТОФАУНЫ КОСТОМУКШСКОГО ЗАПОВЕДНИКА И КАЛЕВАЛЬСКОГО НАЦИОНАЛЬНОГО ПАРКА (СЕВЕРО-ЗАПАД РОССИИ) С УЧЕТОМ ВЛИЯНИЯ ПРИЛЕГАЮЩИХ ТЕРРИТОРИЙ
}

\author{
С. А. Симонов*, М. В. Матанцева \\ Институт биологии Карельского научного иентра РАН, Россия \\ *e-mail: Sergey.Simonov@bio.krc.karelia.ru
}

Публикация посвящена оценке современного состояния орнитофауны Костомукшского заповедника (КЗ) и Калевальского национального парка (КНП) - одних из крупнейших ООПТ Карелии, имеющих большое значение в сохранении эталонных таежных экосистем Зеленого пояса Фенноскандии. Представлена характеристика видового состава и параметров численности птиц обследуемых ООПТ на основании данных 2015-2019 гг. и проведено их сравнение с данными, полученными 20-30 лет назад. Специальное внимание уделено влиянию прилегающих территорий на орнитофауну ООПТ, прежде всего, возможному дистанционному воздействию вырубок, в последние годы появляющихся в непосредственной близости от ООПТ, на орнитофауну периферийных зон этих ООПТ. Исследования были проведены методами маршрутных и точечных учетов с дальнейшей обработкой данных в среде R. Результаты сравнения наших данных с данными, полученными 20-30 лет назад, свидетельствуют в пользу гипотез о смещении в соотношении видов северных экосистем в сторону увеличения доли видов южного происхождения. Наблюдаемое смещение в соотношении видов в исследуемых ООПТ согласуются с представлениями о глобальном смещении в соотношении видов, происходящем в результате изменения климата. При этом на настоящий момент не выявлено критического влияния вырубок на прилегающих к КЗ и КНП территориях на орнитофауну этих ООПТ. Предположительно, значительная площадь ООПТ и режим их охраны компенсирует антропогенную нагрузку на экосистемы. Можно заключить, что при сохранении этих ключевых показателей орнитофауна КЗ и КНП будет сохранена, несмотря на возросший антропогенный пресс на смежных участках. При этом нельзя исключать, что при увеличении площади вырубок вокруг ООПТ и соответствующем росте доли видов открытых стаций часть из них не проникнет в трансформированные зоны и внутри этих ООПТ. Следовательно, необходим дальнейший мониторинг орнитофауны этих ООПТ и особенно их периферийных зон ввиду выявленных тенденций концентрации птиц с южными связями и птиц широкораспространенных видов вблизи нарушенных областей. Наиболее опасные последствия продолжения рубок леса вблизи ООПТ заключаются в более интенсивном проникновении на особо охраняемые природные территории и увеличении численности видов, не являющимися типичными представителями таежных экосистем. Таким образом, продолжающиеся рубки леса могут внести свой вклад в смещение в соотношении видов, вызванное изменением климата, тем самым усугубив ситуацию. Смещение в долях представленности птиц северного и южного происхождения является угрозой дисбаланса таежных сообществ, что, в свою очередь, ведет к возрастанию их уязвимости.

Ключевые слова: антропогенное влияние, вырубки, изменение климата, краевые эффекты, особо охраняемая природная территория, охраняемые виды, птицы, редкие виды, тайга 